\title{
Efficacy of Bacterial Seed Treatments for Controlling Pythium Root Rot of Winter Wheat
}

\author{
E. A. Milus, Assistant Professor, and C. S. Rothrock, Professor, Department of Plant Pathology, University of Ar- \\ kansas, Fayetteville 72701
}

\begin{abstract}
Milus, E. A., and Rothrock, C. S. 1997. Efficacy of bacterial seed treatments for controlling Pythium root rot of winter wheat. Plant Dis. 81:180-184.

Pythium root rot, caused by various Pythium spp., is a widespread disease of wheat. The objective of this study was to identify bacterial strains from wheat roots in Arkansas that suppressed Pythium root rot and to compare their efficacy with that of bacterial strains from other areas. Bacterial strains (applied as seed treatments) that suppressed Pythium root rot in growth chamber assays were evaluated further for in vitro antibiosis against three Pythium spp. and for efficacy under field conditions. Pseudomonas fluorescens strain 2-79R, Burkholderia cepacia strain 1-23, and Pseudomonas sp. strain 1-30 were the most effective for suppressing Pythium root rot under field conditions and significantly $(P=0.10)$ increased yield in one experiment. Strains that were effective in the field also expressed in vitro antibiosis to at least two of three Pythium spp.; however, strains expressing the highest levels of antibiosis were not effective in the field. In the field, root rot suppression and yield enhancement were inconsistent across experiments and generally small in magnitude. Therefore, these strains have little potential for commercial use under the conditions in which they were tested.
\end{abstract}

Pythium root rot of wheat (Triticum aestivum L.) occurs wherever wheat is grown, and is caused by at least $19 P y$ thium spp. (20). Root infections occur mostly on fine rootlets that are difficult to recover from soil. Some infections also occur on seminal and crown roots and produce brown necrotic lesions (4). Aboveground symptoms include stunting, reduced tillering, chlorosis, and delayed maturity but usually go unnoticed because symptoms are fairly uniform over the entire field (20).

Pythium spp. were the most frequently isolated root pathogens from soft red winter wheat in Arkansas (13). No cultivars are resistant to Pythium root rot (20), and fungicide seed treatments were not effective under Arkansas conditions (E. A. Milus and C. S. Rothrock, unpublished). Use of beneficial microorganisms has been proposed for control of soilborne diseases that are not amenable to control with host resistance or chemicals (11).

A diverse group of introduced microorganisms appears to have potential for biological control of soilborne diseases (18). Certain strains of fluorescent pseudomonads were found to control Pythium root rot and increase growth and yield of

Corresponding author: E. A. Milus

E-mail: gmilus@comp.uark.edu

Accepted for publication 2 November 1996.

Publication no. D-1996-1216-04R

(C) 1997 The American Phytopathological Society wheat $(2,19)$. The objective of this research was to identify bacteria from Arkansas that suppressed Pythium root rot and compare their efficacy in suppressing soilborne wheat diseases with that of bacteria found by other researchers. A preliminary report has been published (15).

\section{MATERIALS AND METHODS}

Strains and inoculum production. Candidate biocontrol bacteria were obtained from wheat roots at two locations in 1991 and 1992. Roots were washed in tap water to remove soil, and nine root systems from each location were shaken for $10 \mathrm{~min}$ on a wrist-action shaker in $100 \mathrm{ml}$ of sterile, deionized water with 15 2-mm glass beads to dislodge rhizoplane microorganisms. The suspension was dilution plated in cooled molten 0.1 nutrient strength $(1 / 10)$ Difco tryptic soy agar (TSA) plus $100 \mathrm{mg}$ of cycloheximide per liter and incubated at room temperature. Bacterial colonies were arbitrarily selected and transferred to $1 / 3$ TSA until approximately 150 strains per location and year were obtained. Strains were stored in $15 \%$ dimethyl sulfoxide (DMSO) at $-80^{\circ} \mathrm{C}$, and were identified by fatty acid analysis (MIDI; Newark, DE).

Bacterial strains 2-79 (Pseudomonas fluorescens), L324 (Bacillus sp.), Q29Z80, Q2-87, Q65C-80, 30-84 and Ap-9 (Pseudomonas aureofaciens) were obtained from D. M. Weller (USDA, ARS, Washington State University, Pullman) who identified these strains as suppressive to soilborne wheat pathogens. A stable mutant of 2-79 (2-79R), resistant to $100 \mu \mathrm{g}$ of rifampicin per $\mathrm{ml}$, was selected from the original culture and used in these experiments.

Bacterial strains were applied to wheat seeds by two methods. For growth chamber assays, strains were grown on 1/3 TSA for 2 days and suspended in $5 \mathrm{ml}$ of sterile, deionized water. Seeds (cv. Florida 302) were soaked in the suspension for $20 \mathrm{~min}$ and planted without drying. For field studies, strains were grown in Luria-Bertani broth (17) on a rotary shaker for 2 days at approximately $25^{\circ} \mathrm{C}$. Cells were pelletized by centrifugation at $2,500 \times g$ for $10 \mathrm{~min}$, suspended in $0.01 \mathrm{M}$ phosphate buffer $(\mathrm{pH}$ 7 ), repelletized, and resuspended in buffer. The suspensions were mixed with an equal volume of $1 \%$ methylcellulose in 1991 or $1 \%$ sodium alginate in 1992 and applied to seed at $80 \mathrm{ml} / \mathrm{kg}$ by mixing in a plastic bag. Treated seeds were dried on screens inside a fume hood for 2 to $3 \mathrm{~h}$ and stored at $4^{\circ} \mathrm{C}$ until planted. In 1993 and 1994, the procedures were similar except that no binding agent (methylcellulose or alginate) was used. Treated seeds were planted within 2 days of treatment, except at Keiser in 1991 when seeds were planted 10 days after treatment because of weatherinduced delays.

Pythium irregulare (strain 127-2), $P$. torulosum (strain 109-2) and $P$. graminicola (strain P-1), isolated from wheat roots in Arkansas and pathogenic to wheat seedlings, were used in growth chamber and in vitro assays. For growth chamber assays the Pythium inoculum was grown at room temperature either in 3\% cornmeal-sand medium for 3 weeks or as mycelial mats in potato dextrose broth (stationary culture) for 10 days. Pasteurized Roxana silt loam was infested with cornmeal-sand inoculum at $1,000 \mathrm{CFU} / \mathrm{g}$ as measured by dilution plating or with $0.014 \mathrm{~g}$ of filtered and blended mycelial mat per gram of soil. For in vitro assays the strains were grown on Difco potato dextrose agar (PDA). Strains were stored at $4{ }^{\circ} \mathrm{C}$ on sealed slants of Difco corn meal agar and transferred periodically.

Growth chamber assays. Candidate strains were first screened for efficacy in growth chamber assays. Strains were tested for ability to suppress Pythium root rot with a modification of the tube assay described by Weller and Cook (19). Plastic tubes $2.5 \mathrm{~cm}$ in diameter $\times 16.5 \mathrm{~cm}$ long (Stuewe and Sons Inc., Corvallis, OR) were filled with $2 \mathrm{~cm}$ of infested, pasteurized, Roxana silt loam on top of $10 \mathrm{~cm}$ of 
moist vermiculite. Two treated seeds were placed on top of the soil and covered with $2 \mathrm{~cm}$ of sand-vermiculite $(1: 1, \mathrm{vol} / \mathrm{vol})$. Nontreated seeds were planted in noninfested and Pythium-infested soil as checks in each assay.

After planting, racks of tubes were covered loosely with aluminum foil, kept in the dark for 5 days at $15^{\circ} \mathrm{C}$, then uncovered and kept at $15^{\circ} \mathrm{C}$ with a 14 -h photoperiod. Seedling height was recorded after 14 days as a measure of Pythium root rot severity. Each bacterial strain was tested in two preliminary assays with five replications (tubes) each. Strains with mean seedling heights significantly $(P=0.05)$ greater than the nontreated, infested check and not different from the nontreated, noninfested check in at least one preliminary assay were retested in additional assays to identify the most effective strains.

Strains that increased seedling height in infested soil as described above were tested in tube assays with noninfested soil to determine if the observed increases in seedling height were caused by protection from Pythium root rot or growth promotion. This assay was done twice with four replications.

In vitro assays. Bacterial strains that suppressed root rot in growth chamber assays were tested for inhibition of three Pythium spp. on PDA at $20^{\circ} \mathrm{C}$. Strains were streaked in a 1-cm-wide band across the medium, and PDA plugs $(0.7 \mathrm{~cm}$ diameter) colonized by $P$. irregulare, $P$. torulosum, or $P$. graminicola were transferred to the medium 2 days later with the edge of the plug $20 \mathrm{~mm}$ from the nearest edge of the bacterial growth. The width of the inhibition zone was measured after 4 days. The assays were done twice with three replications each.

Field experiments in 1991 to 1993. Bacterial strains that were the most effective in growth chamber assays were tested in the field at the Northeast Research and Extension Center, Keiser, AR, in 1991 and 1992 and at both Keiser and the Vegetable Substation, Kibler, AR, in 1993. Soil at Keiser was a poorly drained Tunica silty clay ( $\mathrm{pH}$ 6.4), and soil at Kibler was a well-drained Roxana silt loam ( $\mathrm{pH}$ 6.3). Winter wheat was the previous crop at all sites.

Plots were planted in mid to late October with a plot drill equipped with a cone seeder. The experimental design was a randomized complete block with eight replications. Treatments used as checks included metalaxyl (Apron FL at $0.31 \mathrm{~g}$ a.i. per $\mathrm{kg}$ of seed), binder only (methylcellulose, alginate, or phosphate buffer depending on the year), and nontreated seeds. Individual plots were $4.5 \mathrm{~m}$ long $\times 1.2 \mathrm{~m}$ (7 rows) wide. Recommended fertility, weed control, and foliar disease control treatments were applied uniformly across the experimental area as needed.

Extra seeds treated with the bacterial strains were taken to the field at planting time, placed over ice immediately after the plot was planted, and assayed within $36 \mathrm{~h}$ to determine the seed-borne population size of each strain at planting. Three replicates of 10 seeds each were placed in test tubes with $10 \mathrm{ml}$ of sterile, deionized water, agitated on a vortex mixer at high speed for $20 \mathrm{~s}$, allowed to set for $5 \mathrm{~min}$, and agitated again for $20 \mathrm{~s}$. Ten-fold dilution series were made in sterile, deionized water and plated on 1/3 TSA. Isolation plates were incubated at $30^{\circ} \mathrm{C}$, and colonies similar to the original strain were counted after 2 to 3 days.

Plant stand was determined 3 to 4 weeks after planting by counting the number of seedlings in three 1-m-long segments of row per plot. Root infection was determined 4 to 6 weeks after planting by extracting eight soil cores $(7.5 \mathrm{~cm}$ in diameter) with seedlings from each plot. Roots were washed free of soil, and 15 root systems from each plot were excised just above the seed, rinsed under running tap water for $20 \mathrm{~min}$, and disinfested in $0.5 \%$ sodium hypochlorite for $1.5 \mathrm{~min}$. Disinfested root systems were plated individually on $\mathrm{P}_{5} \mathrm{ARP}$ medium (10) and kept at $20^{\circ} \mathrm{C}$. The incidence of Pythium infection was recorded separately for the portion of roots near (within $0.3 \mathrm{~cm}$ ) the point of seed attachment and for the more distal portion of roots. A root system was considered infected if a Pythium sp. was isolated from any portion.

The effect of seed treatment on tillering was determined before harvest by counting the number of heads in three 1-m-long segments of row per plot. Plots were trimmed to $3.3 \mathrm{~m}$ and harvested with a small plot combine. Grain test weight and moisture were determined with a GAC II grain analysis computer (Dickey-john Co., Auburn, IL), and yield was adjusted to $13 \%$ moisture.

The relationship between Pythium infection and yield was determined by PROC CORR (SAS Institute, Cary, NC) on data from individual plots in each field experiment.

Field experiments in 1994. The most effective bacterial strains in previous field experiments (1-23, 1-30, 2-79R, and 5-40) and three additional strains $(\mathrm{Q} 69 \mathrm{c}-80[P$. aureofaciens], L324 [Bacillus sp.], and 3084 [P. aureofaciens]) from D. M. Weller were tested as seed treatments in the field at Keiser and Kibler as described above. In addition, seed treatment with the most effective strains was supplemented with treatments designed to enhance their effectiveness. These supplemental treatments were as follows: (i) the same strain sprayed in-furrow at planting time (approximately $1.5 \times 10^{13} \mathrm{CFU}$ in 738 liters of deionized water per hectare); (ii) metalaxyl fungicide applied to seed with the bacterial strains; and (iii) triple super phosphate fertilizer $(112 \mathrm{~kg} / \mathrm{ha})$ applied in-furrow at planting. In-furrow sprays were applied with a $\mathrm{CO}_{2-}$ powered spray system (R \& D Sprayers, Inc., Opelousas, LA).

In-furrow triple super phosphate fertilizer $(112 \mathrm{~kg} / \mathrm{ha})$ and metalaxyl seed treatment $(0.31 \mathrm{~g}$ a.i. per $\mathrm{kg}$ of seed $)$ followed by a metalaxyl drench (12.4 liters of Ridomil $2 \mathrm{E}$ per ha in 3,582 liters of water) 3 weeks after planting were included as additional checks. The experimental design was a randomized complete block with 24 treatments and eight replications. Bacterial population size on seed at planting, plant stand, incidence of Pythium infection, til-

Table 1. The most effective bacterial strains in growth chamber assays and their in-vitro activity against three Pythium species

\begin{tabular}{|c|c|c|c|c|c|c|}
\hline \multirow[b]{2}{*}{ Strain $^{a}$} & \multirow[b]{2}{*}{ Genus or species } & \multirow[b]{2}{*}{$\begin{array}{c}\text { Similarity } \\
\text { index }^{b}\end{array}$} & \multirow{2}{*}{$\begin{array}{c}\text { Efficacy } \\
\text { chamber } \\
\text { assays }^{c}\end{array}$} & \multicolumn{3}{|c|}{ Inhibition zone in vitro $(\mathbf{m m})^{\mathrm{d}}$} \\
\hline & & & & $\begin{array}{c}P . \\
\text { graminicola }\end{array}$ & $\begin{array}{c}P . \\
\text { torulosum }\end{array}$ & $\begin{array}{c}P . \\
\text { irregulare }\end{array}$ \\
\hline $1-21$ & Arthrobacter oxydans & 0.61 & $3 / 5$ & 0 & 0 & 0 \\
\hline $1-23$ & Burkholderia cepacia & 0.77 & $3 / 5$ & 14 & 15 & 11 \\
\hline $1-30$ & Pseudomonas sp. & 0.56 & $3 / 5$ & 5 & 10 & 0 \\
\hline $2-58$ & B. серасіа & 0.84 & $2 / 5$ & 0 & 5 & 0 \\
\hline $2-79^{*}$ & P. fluorescens & - & $5 / 5$ & 13 & 11 & 6 \\
\hline $5-39$ & Arthrobacter sp. & 0.63 & $2 / 5$ & 0 & 0 & 0 \\
\hline $5-40$ & Pseudomonas sp. & 0.39 & $3 / 5$ & 7 & 8 & 1 \\
\hline $5-58$ & Pseudomonas sp. & 0.63 & $3 / 5$ & 4 & 8 & 0 \\
\hline $5-64$ & (No match) & 0.00 & $3 / 5$ & 0 & 0 & 0 \\
\hline Q29Z-80* & P. fluorescens & - & $2 / 4$ & 8 & 13 & 1 \\
\hline Q2-87* & P. aureofaciens & - & $2 / 4$ & 19 & 20 & 14 \\
\hline Q65c-80* & P. aureofaciens & - & $3 / 4$ & 20 & 20 & 14 \\
\hline Ap9* & P. aureofaciens & - & - & 20 & 12 & 11 \\
\hline
\end{tabular}

${ }^{a}$ Strains marked with an asterisk $(*)$ were obtained from and identified by D. M. Weller; other strains were isolated by the authors.

${ }^{\mathrm{b}}$ Strains were characterized by fatty acid analysis by R. K. Jones, University of Minnesota, with the Microbial Identification System (MIDI, Inc., Newark, DE, version 3.8). Strains with a similarity index $>0.50$ were considered good matches to the genus or species, and those with indices 0.30 to 0.49 were good matches but possibly atypical strains.

${ }^{\mathrm{c}}$ Number of assays in which strain gave significant $(P=0.05)$ control of Pythium root rot compared with the number of assays in which it was tested

${ }^{\mathrm{d}}$ An inhibition zone of $20 \mathrm{~mm}$ indicated that the fungus did not grow toward the bacterial strain. 
lering, yield, and test weight were measured as described previously. Concentration of bacterial strains in in-furrow inoculum was determined by dilution plating a residual aliquot that was transported from the field to the laboratory over ice.

\section{RESULTS}

Growth chamber assays. More than 600 bacterial strains from wheat roots in Arkansas were screened for biocontrol of Pythium root rot in growth chamber assays. Strain 2-79R was the most effective, significantly suppressing Pythium root rot in five out of five assays (Table 1). Eight strains from Arkansas and three strains from D. M. Weller suppressed Pythium root rot in at least two assays. A number of strains appeared effective in one preliminary assay but were ineffective in subsequent assays (data not shown). None of the strains increased seedling height in noninfested soil (data not shown).

In vitro assays. Of the strains that were most effective in the growth chamber assays, three (strains 1-21, 5-39, and 5-64) were not inhibitory to any Pythium spp. tested, one (strain 2-58) was slightly inhibitory to $P$. torulosum, two (strains 1-30 and 5-58) were inhibitory to $P$. torulosum and $P$. graminicola, and seven (strains 123, 2-79R, 5-40, Q29Z-80, Q2-87, Q65c80 , and Ap9) were inhibitory to all three species (Table 1). All Pseudomonas strains were inhibitory to at least two of three $P y$ -

Table 2. Effect of seed treatment on incidence of Pythium infection on wheat seedlings 4 to 6 weeks after planting

\begin{tabular}{lcccc}
\hline & \multicolumn{3}{c}{$\begin{array}{c}\text { Incidence of Pythium infection } \\
\text { (\% root systems infected) }\end{array}$} \\
\cline { 2 - 4 } $\begin{array}{l}\text { Seed } \\
\text { treatment }\end{array}$ & $\mathbf{4}$ Keiser & Kibler \\
\cline { 2 - 4 } $1-21$ & - & - & 54 & 89 \\
$1-23$ & 93 & $54^{* a}$ & 70 & 94 \\
$1-30$ & 95 & $58^{*}$ & 75 & 88 \\
$2-58$ & 83 & 67 & 74 & 88 \\
$2-79$ & 93 & $58^{*}$ & 60 & $81^{*}$ \\
5-39 & 97 & 69 & 51 & 97 \\
5-40 & 85 & 65 & 72 & 96 \\
5-58 & - & - & 78 & 94 \\
5-64 & 88 & 68 & 65 & 94 \\
Q29Z-80 & - & - & 66 & 93 \\
Q2-87 & - & - & 75 & 93 \\
Q65c-80 & - & - & 54 & 93 \\
Ap9 & - & - & 73 & 89 \\
Nontreated & 93 & 75 & 55 & 95 \\
Binder & 97 & 71 & 67 & 93 \\
Metalaxyl & - & 63 & 47 & $85^{*}$ \\
Prob.> F & 0.27 & 0.05 & 0.04 & 0.003 \\
LSD & NS & 16 & 19 & 8 \\
\hline
\end{tabular}

a Means within each column marked with an asterisk $(*)$ were significantly $(P=0.05)$ less than the nontreated check.

${ }^{b}$ Binders used to apply bacterial strains were $1 \%$ methylcellulose, $1 \%$ sodium alginate, and phosphate buffer for 1991, 1992, and 1993, respectively.

${ }^{\mathrm{c}}$ Least significant difference $(P=0.05)$; NS $=$ not significant. thium spp. tested. Strains of $P$. aureofaciens were the most inhibitory. Of the $P y$ thium spp. tested, $P$. irregulare had the fastest growth rate (data not shown) and was inhibited to a lesser degree than $P$. graminicola or $P$. torulosum.

Field experiments in 1991 to 1993. Population size of bacterial strains on seeds at planting varied among strains and experiments, but generally was $\geq \log _{10} 6.0$ CFU/seed (data not shown). Strains of $P$. aureofaciens (Q2-87, Q65c-80, and Ap-9) and strain $1-23$ of $P$. cepacia had population sizes $\leq \log _{10} 6.0 \mathrm{CFU} /$ seed in 1993 .

Seed treatment had a significant $(P=$ 0.05 ) effect on incidence of Pythium infection in three of four location-years (Table 2). Compared with the nontreated check, strains 1-23, 1-30, and 2-79R reduced incidence of infection at Keiser in 1992, and strain 2-79R reduced incidence of infection at Kibler in 1993. At Keiser in 1993, incidence of infection for the nontreated check was only $55 \%$, and several treatments had a significantly greater incidence of infection, but none had a lower incidence of infection. Metalaxyl reduced the incidence of infection at Kibler in 1993. The binder had no effect in any location-year.

Seed treatment had no effect on yield, plant stand, Pythium infection near the seed, tillering, or test weight (data not shown). The relationships between incidence of Pythium infection near the seed and yield was weakly negative $(r=-0.25$, $P=0.008)$ at Kibler in 1993 and weakly positive $(r=0.26, P=0.007)$ at Keiser in 1993. Relationships between Pythium infection and yield were not statistically significant in other field experiments.

Field experiments in 1994. Population size of bacterial strains on seed at planting ranged from $\log _{10} 5.6$ to 7.5 and 7.0 to 8.4 $\mathrm{CFU} / \mathrm{seed}$ at Keiser and Kibler, respectively (data not shown). Application rates for in-furrow sprays of bacterial strains were similar and ranged from $\log _{10} 7.2$ to 7.6 and 7.4 to $7.5 \mathrm{CFU} / \mathrm{m}$ row at Keiser and Kibler, respectively.

Incidence of Pythium infection was high at both Keiser and Kibler (Table 3). Metalaxyl (Apron $30 \mathrm{FL}$ ) seed treatment followed by a metalaxyl (Ridomil 2E) soil drench at both locations and strain 5-40 plus metalaxyl seed treatment at Kibler reduced the incidence of infection on a root system basis. A greater number of treatments reduced the incidence of infection near the point of seed attachment (Table 3). Metalaxyl and strain 2-79R seed treatments appeared to be responsible for the reduced infection at Keiser and Kibler, respectively. Seed treatment with both strain 2-79R and metalaxyl was the only treatment that reduced infection at both locations.

Plant stand was not significantly different among treatments at either location (data not shown). The experiment at Keiser was severely damaged by standing water over the winter and could not be evaluated for tillering, yield, and test weight. At Kibler, eight treatments had significantly $(P=$ $0.10)$ greater yield than the nontreated check (Table 3). These treatments included strains 1-23, 2-79R, and 5-40 as seed treatments, 1-23 plus metalaxyl, 1-23 plus in-furrow spray, 5-40 plus metalaxyl, metalaxyl alone, and in-furrow phosphorus. No treatment significantly increased tillering or test weight (data not shown). At Kibler, incidence of Pythium infection near the seed and incidence of root systems infected by Pythium spp. were weakly and negatively related to yield $(r=-0.22, P=$ 0.013 , and $r=-0.23, P=0.009$, respectively).

\section{DISCUSSION}

This study demonstrated that several bacterial strains inhibited Pythium spp. in vitro and frequently suppressed Pythium root rot in growth chamber assays. However, in the field, root rot suppression and yield enhancement were inconsistent across experiments and generally small in magnitude. Therefore, these strains have little potential for commercial use under the conditions in which they were tested.

Population size of bacterial strains on seeds at planting has been shown to be positively correlated with population size of strains in the rhizosphere $(3,14)$, and some seed-borne populations in this study may have been inadequate for maximum efficacy.

All bacterial strains that reduced incidence of Pythium root rot or increased yield under field conditions were inhibitory to at least two of three Pythium spp. used in in-vitro assays; however, three $P$. aureofaciens strains that had the greatest inhibitory effect were not effective in the field. These results agree with previous reports $(1,18)$ that antibiosis (in vitro inhibition) is one mechanism for biological control, but there is no relationship between levels of inhibition and biological control.

Strain 2-79R was one of the most consistently effective strains for controlling Pythium root rot in growth chamber assays and in the field and was moderately inhibitory to three Pythium spp. in vitro. This strain also was among the best colonizers of the wheat rhizosphere at Kibler and Keiser in previous experiments (14). Mazzola and Cook (12) reported that strain 2$79 \mathrm{RN}_{10}$, a mutant of $2-79$ resistant to rifampicin and nalidixic acid, was not inhibitory to three Pythium spp. (including $P$. irregulare) and that rhizosphere populations of strain $2-79 \mathrm{RN}_{10}$ were inhibited by populations of Pythium spp. in the soil. Strain 2-79R appears to be more effective than strain 2-79RN $\mathrm{R}_{10}$ against Pythium spp..

In this study, it appeared that infection of wheat seedlings in the fall by Pythium spp. had only small, variable effects on yield. However, none of the treatments gave sufficient control of Pythium root rot to estimate the yield potential in the ab- 
79:1142.

14. Milus, E. A., and Rothrock, C. S. 1992. Rhizosphere colonization of wheat by selected soil bacteria over diverse environments. Can. J. Microbiol. 39:335-341.

15. Milus, E. A., Rothrock, C. S., and Rhoads, M.

L. 1992. Control of Pythium root rot of wheat in the field with bacterial seed treatments. (Abstr.) Phytopathology 82:1128.

16. Rhoads, M. L., Rothrock, C. S., and Milus, E.
A. 1993. Incidence and identification of $P y$ thium spp. pathogenic on soft red winter wheat in Arkansas. (Abstr.) Phytopathology 83:1387.

17. Sambrook, J., Fritsch, E. F., and Maniatis, T. A. 1989. Molecular Cloning: A Laboratory Manual. 2nd ed. Cold Spring Harbor Laboratory, Cold Spring Harbor, NY.

18. Weller, D. M. 1988. Biological control of soilborne plant pathogens in the rhizosphere with bacteria. Annu. Rev. Phytopathol. 26: 379-407.

19. Weller, D. M., and Cook, R. J. 1986. Increased growth of wheat by seed treatments with fluorescent pseudomonads, and implications of Pythium control. Can. J. Plant Pathol. 8:328-334.

20. Wiese, M. V. 1987. Compendium of Wheat Diseases. 2nd ed. American Phytopathological Society. St. Paul, MN. 